\title{
THE INTERNATIONAL RESEARCH OF ACADEMIC ECONOMISTS IN BRAZIL: 1999-2006*
}

\author{
João Ricardo Faria ${ }^{\S}$ \\ Ari Francisco de Araujo Jr. \\ Cláudio D. Shikida ${ }^{\dagger}$
}

\begin{abstract}
RESUMO
Este paper estende a análise de Faria (2000) para o período de 1999-2006. O estudo analisa a produção de 750 economistas acadêmicos de 31 departamentos de economia com programas de pós-graduação no Brasil. Ao nível individual, somente 12 economistas conseguiram publicar pelo menos um artigo nas revistas acadêmicas mais importantes da profissão, e 96 economistas publicaram pelo menos um artigo nas revistas da lista de revistas internacionais. As áreas de pesquisa em que os brasileiros são mais bem sucedidos são: Economia Aplicada, Desenvolvimento Econômico, Economia Matemática e Economia Pós-Keynesiana. Há uma diferença marcante de qualidade entre os departamentos. A performance dos departamentos depende de esforços isolados de indivíduos. O número total de artigos publicados, de pesquisadores publicando em revistas internacionais e departamentos com membros publicando em revistas internacionais, cresceu durante o período.
\end{abstract}

Palavras-chave: rankings de departamentos e economistas, papel dos economistas.

\begin{abstract}
This paper extends Faria (2000) analysis to the period of 1999-2006. The study analyzes the production of 750 Brazilian academic economists from 31 departments of economics with graduate programs. At individual level, only 12 out of 750 economists managed to publish at least one paper in the top journals of economics, and 96 economists published at least one paper in a wide list of international journals. The areas in which Brazilian research is most internationally successful are: Applied Economics, Development Economics, Mathematical Economics and Post-keynesian Economics. There is a remarkable difference in quality among departments. The performance of departments depends on isolated individual's efforts and achievements. The results show that Brazilian academic research in economics has improved. The total numbers of international papers published, of researchers publishing in international journals, and departments with members with international publications have increased during this period.
\end{abstract}

Key words: rankings of departments and economists, role of economists.

JEL classification: A11, D29, I29.

\footnotetext{
* Acknowledgements: we would like to thank, without implicating, Cristiane M. Carneiro, and Pedro H.C. de Sant'Anna for their research assistance, and Jorge S. Arbache, André R. Oliveira, Emanuel Ornelas, and Adolfo Sachsida for comments.

$\S$ Nottingham Business School. Address for correspondence: Nottingham Business School, Nottingham Trent University, Burton Street, Nottingham NG1 4BU, United Kingdom. E-mail: jockafaria@hotmail.com.

a Centro de Economia Aplicada e Estratégia Empresarial, Ibmec Minas Gerais. E-mail: arifaj@ibmecmg.br.

$\dagger$ Centro de Economia Aplicada e Estratégia Empresarial, Ibmec Minas Gerais. E-mail: : claudiods@ibmecmg.br.

Recebido em junho de 2007. Aceito para publicação em setembro de 2007.
} 


\section{INTRODUCTION}

Over the past decade Brazilian academic economists realized that academic merit can and must be assessed objectively. ${ }^{1}$ A number of articles have been published analyzing their contributions to domestic journals, international journals, impact on the literature and patterns of citations. Gonçalves and David (1982) and Azzoni (1998, 2000) measure the output of Brazilian researchers and academic departments in Brazilian domestic journals. Faria (2000) and Issler and Pilar (2002) examine publications of Brazilian academic economists in international journals. Issler and Ferreira (2004) evaluate the performance of Brazilian economists through citations in international journals. Faria et al. (2007) analyze the citation pattern of Brazilian economists.

The picture that emerges from these studies is that Brazilian economists have little international insertion and impact. These results are in line with international rankings published by Kalaitzidakis et al. (2003), Garcia-Castrillo et al. (2002) and Coupé (2003). These rankings show that Brazilian economists and departments have negligible international penetration and impact.

The objective of this paper is to extend Faria (2000) productivity rankings of economists and departments as regards to publications in international economic journals. Faria (2000) paper covers the period of 1983 to early 1999. This paper analyzes the period from 1999 to 2006.

It is important to stress that the measurement of the output of Brazilian academic researchers in international journals is an inexpensive and efficient way to assess their research in terms of quantity and quality. The quality dimension is related to the fact that the main research in economics is published in English in a set of widely read and cited international journals. In addition, the rankings generated by this exercise allow public research agencies to evaluate and reward departments and economists. Last but not least, rankings of this type are of paramount importance to researchers that struggle for peer recognition. Peer recognition is, according to Samuelson (1995), one of the most important aspects of a scholar's incentives.

The important question answered by this study is the following: Has Brazilian economic research improved recently or not? The answer is yes. Brazilian academic research in economics as measured by international publications has improved substantially. The total number of papers published in international journals, the number of researchers publishing in international venues, and the number of departments with members with international publications have increased.

The paper is divided as follows. The next section explains the methodology of the paper. Section three shows the rankings of departments. Section four presents the rankings of economists. Section five discusses the results. The concluding remarks appear in section six.

\section{Methodology}

The source of information is the online version of EconLit, which is the most often used and widely accepted database for publications in economics. We searched the publications in international journals of the members of economics departments affiliated to Anpec. The names of the economists associated with these departments are drawn from the departments' homepages. We recorded all international publications during the period of 1999-2006.

1 The change of perception is also reflected by the government research agencies such as CAPES, see Faria (2004). 
There are two sets of journals upon which the rankings are based. The first set of journals is the "Blue Ribbon" journals as in Dusansky and Vernon (1998), which comprises some of the top journals in economics: American Economic Review (AER), Econometrica; Journal of Political Economy (JPE), Quarterly Journal of Economics (QJE), Review of Economic Studies (RES), Journal of Economic Theory (JET), International Economic Review (IER), and Review of Economics and Statistics (REST). ${ }^{2}$ The second set of journals, named wide list of economic journals, encompasses the blue ribbon journals and has more than 120 journals representative of all areas of research in economics. The wide list appears in the appendix. This list is basically the same list used by Faria (2000) - which is a combination of Fox and Milbourne (1999) and the list in Table A2 of Laband and Piete (1994) - with some brand new journals added. The data was collected during the period of July 2006 and April 2007.

Some caveats are necessary. First, Brazilian names are long, which may lead to identification problems, since some authors may have been recorded by their middle names. Second, whenever confusion arises, we tried to access other sources of information, such as departmental, personal and/or CNPq's researchers' homepages. Unfortunately, a large number of departments and researchers do not update or maintain homepages. Third, during the period of 1999-2006 a number of economists left or were added to the departments analyzed. We considered the output of the economists that left some departments and went abroad that we know of. For the economists that changed departments in Brazil, we recorded their output as pertaining to the actual departments.

In total we analyzed 750 academic economists; they are members of 31 economic departments with graduate programs that are affiliated to Anpec. In our sample we consider all professors of the following departments: 1) Fundação Getúlio Vargas Rio de Janeiro (FGV-RJ), 2) Fundação Getúlio Vargas São Paulo (FGV-SP), 3) Universidade de Brasília (UnB), 4) Universidade Federal do Rio de Janeiro (UFRJ).

For the following departments we considered the professors associated with the graduate programs (master and/or Ph.D.): 5) Pontifícia Universidade Católica Rio de Janeiro (PUC-RJ), 6) Pontifícia Universidade Católica São Paulo (PUC-SP), 7) Pontifícia Universidade Católica Rio Grande do Sul (PUC-RS), 8) Universidade Federal do Rio Grande do Sul (UFRGS), 9) Universidade de São Paulo (USP), 10) Universidade de São Paulo Ribeirão Preto (USP-RP), 11) Universidade Federal do Pará (UFPA), 12) Universidade Estadual de Maringá (UEM), 13) Universidade Federal de Minas Gerais (UFMG), 14) Universidade Estadual do Rio de Janeiro (UERJ), 15) Universidade Católica de Brasília (UCB), 16) Universidade Estadual de São Paulo (UNESP), 17) Universidade de Campinas (UNICAMP), 18) Universidade Federal de Juiz de Fora (UFJF), 19) Universidade Federal do Paraná (UFPR), 20) Universidade Federal Fluminense (UFF), 21) Universidade Federal da Bahia (UFBA), 22) Universidade Federal de Santa Catarina (UFSC), 23) Universidade Federal do Ceará (UFC), 24) Universidade Federal de Pernambuco (UFPE), 25) Universidade Federal da Paraíba (UFPB), 26) Universidade Federal do Rio Grande do Norte (UFRN), 27) Universidade Federal de Uberlândia (UFU), 28) Universidade Federal de Viçosa (UFV), 29) Universidade Federal do Espírito do Santo (UFES).

Finally for 30) IBMEC-RJ, we considered the professors associated with their master program, in spite of posterior changes in their homepage, and for 31) IBMEC-SP, we analyzed the full time professor plus two others associated with their master program.

2 Regarding the top journals of economics, the inclusion of International Economic Review and Review of Economics and Statistics in the list is controversial (e.g., Kim et al., 2006), since by impact factor and by the opinion of many economists there are journals more important, such as Journal of Finance, Journal of Monetary Economics, and the Economic Journal, to list a few. 


\section{RANKINGS OF DEPARTMENTS}

The ranking of economic departments appears in Table 1. The departments are listed according to their productivity in terms of international publications. The first column after the names of the schools shows the number of academic staff for each department. The next column shows total number of papers published by members of the department in the wide list of economic journals. This number takes into account co-authorship in the department. In order to avoid double counting of papers, just one paper is recorded when it is co-authored by more than one member of the same department. The fourth column is the relative productivity per member of the department; it is calculated by dividing the number of international publications by the number of members of the academic staff. The following column presents the number of publications in the blue ribbon journals. The last column is the departmental productivity according to publications in blue ribbon journals.

The figures in Table 1 are quite interesting. The members of 11 out of 31 departments did not publish any paper in the journals of the wide list over the period of 1999-2006, i.e., 35\% of the departments with graduate economic degrees do not have researchers publishing in international journals of the wide list over the past seven years. In spite of showing that economic research has poor standards in Brazil, these figures when compared with Faria (2000) Table 1 show an impressive improvement. According to Table 1 in Faria (2000), 12 out of 20 departments - 60\% of departments - did not publish any article in the wide list of economic journals over the period of 15 years, from 1983 to 1999.

As pointed out by Faria (2000) and Issler and Pilar (2002), there is a remarkable difference in quality among the economic departments in Brazil. There appears to be a segmented market in which schools such as FGV-RJ and PUC-RJ stand out as centers of excellence, followed by UCB, $\mathrm{UnB}$, USP and the IBMECs of RJ and SP.

It is worth noticing that among these seven top departments, only two are public universities, the remaining are private schools. As private schools have greater flexibility in setting salaries and providing incentives for publication, as well as hiring and firing academic personnel, their lead position in the ranking should not come as a surprise. Besides that, tradition and personal ties help explain this picture. FGV-RJ and PUC-RJ have a long tradition of attracting the best master students of Brazil and sending them to the leading Ph.D. programs in economics in the world. After these students complete their doctorates they are invited back to these schools where they face positive incentives to perform at the highest levels of research (see Franco, 2007). For these schools the path dependence hypothesis appears to fit well. However, there are new players in the market with different strategies. The dramatic rise of UCB is an example of academic vision and entrepreneurial activity attached to a small number of economists that created a top department inside a university with a research-averse mentality. It shows that the micro management of departments as teams with clear objectives toward research achievement is possible in spite of all adversities. ${ }^{3}$

3 Conversely, Besancenot and Vranceanu (2007) present a model where large bonuses as rewards for publications might bring unpleasant consequences, such as a drop in quality of top journals, a decline in the number of top-tier publications and a fall in the expected compensation of top researchers. 
Table 1

\begin{tabular}{|c|c|c|c|c|c|}
\hline Dept & Staff & Publications & Publ/Staff & Blue Ribbon & B.R./Staff \\
\hline FGV-RJ & 25 & 57 & 2.28 & 8 & 0.32 \\
\hline UCB & 11 & 15 & 1.36 & 0 & 0.00 \\
\hline PUC-RJ & 18 & 18 & 1.00 & 4 & 0.22 \\
\hline UNB & 32 & 32 & 1.00 & 0 & 0.00 \\
\hline USP & 45 & 30 & 0.67 & 1 & 0.02 \\
\hline UNICAMP $^{4}$ & (84) 17 & (9) 7 & (0.11) 0.41 & 0 & 0.00 \\
\hline IBMEC-SP & 23 & 9 & 0.39 & 1 & 0.04 \\
\hline IBMEC-RJ & 28 & 10 & 0.36 & 1 & 0.04 \\
\hline PUC_RS & 9 & 3 & 0.33 & 0 & 0.00 \\
\hline UFRGS & 31 & 8 & 0.26 & 0 & 0.00 \\
\hline USP_RP & 18 & 4 & 0.22 & 0 & 0.00 \\
\hline UERJ & 16 & 3 & 0.19 & 0 & 0.00 \\
\hline UFMG & 24 & 4 & 0.17 & 0 & 0.00 \\
\hline UFRJ & 89 & 12 & 0.13 & 0 & 0.00 \\
\hline UNESP & 16 & 2 & 0.13 & 0 & 0.00 \\
\hline FGV-SP & 46 & 4 & 0.09 & 0 & 0.00 \\
\hline UFPR & 14 & 1 & 0.07 & 0 & 0.00 \\
\hline UFJF & 14 & 1 & 0.07 & 0 & 0.00 \\
\hline UFF & 19 & 1 & 0.05 & 0 & 0.00 \\
\hline UEM & 19 & 1 & 0.05 & 0 & 0.00 \\
\hline UFES & 9 & 0 & 0.00 & 0 & 0.00 \\
\hline UFSC & 10 & 0 & 0.00 & 0 & 0.00 \\
\hline UFU & 17 & 0 & 0.00 & 0 & 0.00 \\
\hline PUC-SP & 13 & 0 & 0.00 & 0 & 0.00 \\
\hline UFPA & 22 & 0 & 0.00 & 0 & 0.00 \\
\hline UFV & 13 & 0 & 0.00 & 0 & 0.00 \\
\hline UFPB & 15 & 0 & 0.00 & 0 & 0.00 \\
\hline UFRN & 14 & 0 & 0.00 & 0 & 0.00 \\
\hline UFPE & 17 & 0 & 0.00 & 0 & 0.00 \\
\hline UFC & 23 & 0 & 0.00 & 0 & 0.00 \\
\hline UFBA & 16 & 0 & 0.00 & 0 & 0.00 \\
\hline
\end{tabular}

The third level of quality is filled by PUC-RS, UFRGS, UFMG, USP-RP, UERJ, UFRJ, UNESP, UNICAMP, FGV-SP, UFJF, UFPR, UEM, and UFF. Finally the lower levels are occupied by those schools whose members did not publish any international paper in the journals of the wide list over the period considered.

As pointed out by Faria (2000) departmental productivity is driven by the achievements of a limited number of individuals. The majority of departments are heterogeneous, where a small number of individuals are responsible for most of the papers published in internationals journals. This can be easily seen by considering Table 2 .

The first column of Table 2 presents the school name; the second column depicts the number of academic staff, while the third column shows the number of academic staff that published at least one paper in the journals of the wide list. The fourth column shows the proportion of members of the department with international publications in the wide list of economic journals.

4 UNICAMP has 84 academic staff members, however it puts only 17 as teaching at the graduate level 
Table 2

\begin{tabular}{lccc}
\hline Dept & Staff & St.Pub. & St.Pub./Staff \\
\hline FGV-RJ & 25 & 16 & 0.640 \\
UCB & 11 & 7 & 0.636 \\
PUC-RJ & 18 & 9 & 0.50 \\
USP & 45 & 15 & 0.33 \\
IBMEC-SP & 23 & 6 & 0.26 \\
UNB & 33 & 8 & 0.24 \\
USP_RP & 18 & 4 & 0.22 \\
IBMEC-RJ & 28 & 5 & 0.18 \\
UFMG & 24 & 4 & 0.17 \\
UERJ & 16 & 2 & 0.13 \\
PUC_RS & 9 & 1 & 0.11 \\
UFRGS & 31 & 3 & 0.10 \\
FGV-SP & 46 & 4 & 0.09 \\
UFJF & 14 & 1 & 0.07 \\
UFPR & 14 & 1 & 0.07 \\
UFRJ & 89 & 6 & 0.07 \\
UNESP & 16 & 1 & 0.06 \\
UNICAMP & 17 & 1 & 0.06 \\
UEM & 19 & 1 & 0.05 \\
UFF & 19 & 1 & 0.05 \\
\hline
\end{tabular}

According to Table 2, only two departments, FGV-RJ and UCB, have more than $50 \%$ of its personnel publishing in journals of the wide list. This is an important indicator that signals whether a department as a whole is committed to high quality research. PUC-RJ, USP and IBMEC-SP have between $50 \%$ and $25 \%$. The great majority of departments with international publications have less than $20 \%$ of its academic staff involved in quality research.

In order to stress the point raised above that the majority of departments depend on the achievements of isolated individuals, let us consider the case of UNICAMP. Regardless its reputation as one of the best universities of Brazil, the department of economics of UNICAMP is a typical example of the poverty of international research in economics in Brazil. UNICAMP has 84 scholars, but only three have published in international journals of the wide list since 1999. Moreover, one researcher alone, David Dequech, is responsible for 7 of the 9 papers recorded by the department as a whole. UNICAMP has recently updated its homepage and the graduate program presents only 17 academic staff members. Considering this number the relative position of UNICAMP changes dramatically since Dequech remains in this list, and the ratio publication/staff increases from 0.11 to 0.41 and the ratio staff publishing/staff raises from 0.04 to 0.06 . Still these figures are rather dismal for such overrated graduate program.

As per the lower levels of department quality, Table 3 presents departments with academic staff that did not publish in the wide list of journals but published in international journals. Examples of these journals are: Applied Economics Letters, Economics Bulletin, Revista de Analisis Económico, Journal of Economic Integration, Journal of Cultural Economics, Journal of Empirical Finance, Latin American Politics and Society, Economics and Politics, Journal of Economic Issues, Research Policy, American Journal of Economics and Sociology, and CEPAL Review. It is also worth 
noticing that some productive economic researchers, such as Sérgio da Silva of UFSC and Daniel Cajueiro of UCB, are regularly publishing in the top journals of other fields, such as Physics.

In Table 3, the first column shows the department name, the second column the number of academic staff, the third column presents the number of academic staff that published at least one paper in international journals that do not appear in the wide list. Among 9 departments, only three have $20 \%$ or more of its members publishing abroad. However, when compared with Table 3 in Faria (2000) one can see that the number of departments and researchers with international publications increased over the period.

Table 3

\begin{tabular}{lccc}
\hline Department & Staff & St.Pb.Int & St.Pb.Int/Staff \\
\hline UFU & 17 & 4 & 0.24 \\
UFES & 9 & 2 & 0.22 \\
UFSC & 10 & 2 & 0.20 \\
UFPA & 22 & 2 & 0.09 \\
PUC-SP & 13 & 1 & 0.08 \\
UFV & 13 & 1 & 0.08 \\
UFRN & 14 & 1 & 0.07 \\
UFPB & 15 & 1 & 0.07 \\
UFPE & 17 & 1 & 0.06 \\
\hline
\end{tabular}

Table 4 presents the only two departments without any international publications over the period of 1999-2007. In order to classify them we considered the number of academic staff that published in domestic journals ${ }^{5}$ (St.Pb.Nat). Contrasting Table 4 with Faria's (2000) Table 4, one can see that the number of departments only publishing in domestic journals has decreased from five to two.

Table 4

\begin{tabular}{lrcc}
\hline Dept. & Staff & St.Pb.Nat & St.Pb.Nat/Staff \\
\hline UFC & 23 & 11 & 0.48 \\
UFBA & 16 & 1 & 0.06 \\
\hline
\end{tabular}

The evidence presented in Tables 1 to 4 shows that the number of papers, researchers and departments publishing in international journals has increased in Brazil recently.

\section{RANKINGS OF ECONOMISTS}

The rankings of economists presented below are based on their publications in international journals, so it is a productivity ranking. If an economist has a large number of international publications it does not follow necessarily that he/she is a leading economist. In order to assess their

5 The journals are: Economia e Sociedade; Estudos Econômicos; Pesquisa e Planejamento Econômico; Revista Brasileira de Economia; Revista de Econometria; Revista de Economia e Sociologia Rural; Revista de Economia Política. 
impact on the literature, a better measure is to consider the number of citations of their work in other researchers' work.

Table 5 presents the ranking of the Brazilian economists that published in the blue ribbon journals. The first column presents the name of the researcher, the second column his/her affiliation, the third column registers the number of papers in blue ribbon journals, and the last column the names of the journals where the papers were published.

The total number of economists examined in this study is 750 , over the past seven years only 12 economists managed to publish at least one paper in the top journals of the profession. Of course, a publication in the top tier economic journals is a great achievement, and only a few are able to do so. However in the Brazilian case only about $1.6 \%$ of its researchers succeeded. In Faria (2000) out of 506 economists, only 9 managed to publish in the blue ribbon journals over a period of 15 years, i.e., about $1.8 \%$ of the total.

Notice that one economist alone, Rodrigo Soares, published two papers in the premier journal of the profession, the American Economic Review (AER). ${ }^{6}$ This is a great achievement since as recorded in Faria (2000) no Brazilian economist working in academic departments in Brazil has published a single paper in AER in the period of 1983-1999. Rodrigo Soares is affiliated with PUC-RJ and the University of Maryland. Another economist publishing in top journals, Emanuel Ornelas, also has a double appointment in Brazil and the USA, in his case at IBMEC-RJ and the University of Georgia. ${ }^{7}$ This is not a coincidence. Actually their double appointment just confirms the importance of their achievements and research status.

The leading Brazilian economists Aloísio Araújo, Marilda Sotomayor and Paulo Klinger Monteiro also appear in the list. They are the only economists that also appear in Table 5 of Faria (2000). ${ }^{8}$ Their consistency is an evidence of their high quality research.

As in Faria (2000) the researchers in Table 5 are concentrated in FGV-RJ and PUC-RJ. The novelty is that there are two researchers, one in each IBMEC, RJ and SP. There are 12 scholars in Table 5, which contrasts with 9 scholars in Faria (2000), showing that the number of Brazilian scholars publishing in the top tier journals in economics has increased. Four out of these twelve researchers received their Ph.D. degrees in Brazil, two at IMPA (Monteiro and Torres-Martínez), one at PUC-RJ (Sotomayor) and another at USP (Pessôa); the remaining scholars received their Ph.D. degrees in the top US universities, two at Chicago (Soares and Costa), Yale (Rossi Junior), MIT (Goldfajn), Pennsylvania (Ferreira), Wisconsin (Ornelas), Berkeley (Araújo) and Minnesota (Cavalcanti). Notice that four of these researchers have Ph.D. degrees outside typical economics programs, such as in statistics, mathematics and mathematical economics (Araújo, Sotomayor, Monteiro and Torres-Martínez).

6 It is worth noticing that one of Soares' papers is co-authored by the Nobel Prize laureate Gary Becker. Incidentally, there are other economists in Brazil that co-authored and published papers with Nobel Prize laureates as well, such as João Victor Issler who published with Robert Engle, and Guilherme Sedlacek, formely at IPEA-RJ (not included in our sample), who published a number of papers with James Heckman, and Finn Kydland.

7 There are other cases of productive scholars, such as the case of Luis Araújo, who is not in our sample, who has double appointment in Fucape in Espirito Santo, and Michigan State University.

8 Note that Ilan Goldfajn also appears in both tables, however the year 1999 was considered in both samples and it computes the same Goldfajn's article in QJE. 
Table 5

\begin{tabular}{llll}
\hline Name & Dept. & B.R. & Journals \\
\hline Aloisio Pessoa de Araújo & FGV-RJ & 2 & 2-Econometrica \\
Ricardo Cavalcanti & FGV-RJ & 2 & 1- JPE 1-Int.Econ.Review \\
Rodrigo Reis Soares & PUC_RJ & 2 & 2 AER \\
Emanuel Ornelas & IBMEC RJ & 1 & QJE \\
Carlos E. da Costa & FGV-RJ & 1 & JPE \\
Paulo Klinger Monteiro & FGV-RJ & 1 & JET \\
Pedro Cavalcanti Ferreira & FGV-RJ & 1 & Int.Econ.Review \\
Samuel Pessôa & FGV-RJ & 1 & Int.Econ.Review \\
Ilan Goldfajn & PUC_RJ & 1 & QJE \\
Juan Pablo Torres-Martínez & PUC_RJ & 1 & Econometrica \\
José Luiz Rossi Júnior & IBMEC SP & 1 & Int.Econ.Review \\
Marilda A. de O. Sotomayor & USP & 1 & JET \\
\hline
\end{tabular}

In total there are 14 papers published in blue ribbon journals, 4 papers in IER, 2 in JPE, 2 in AER, 2 in Econometrica (one of them is co-authored by Araújo and Torres-Martínez), 2 in JET and 2 in QJE. The fields of these papers are: Mathematical economics, monetary economics, health economics and international economics.

Table 6 presents the ranking of the most productive Brazilian academic economists. It accounts the ones that published at least one paper in the international journals of the wide list. It should be stressed that the ranking is based on the absolute number of papers published without taking into account the relative importance of the journals were they appear. It also ignores whether the paper is a solo or co-authored paper. If the journals' weights based on citations and/or co-authorship is taken into account the ranking would be different.

The first column in Table 6 presents the scholar's name, the second column his/her affiliation, the third column the school where he/she received the Ph.D. degree, the fourth column is the country of the Ph.D. school and the last column presents the number of papers published over the period of 1999-2006.

In a universe of 750 economists, only 96 managed to publish at least one paper in an international journal of the wide list of journals, that is, $12.8 \%$ of the economists. In Faria (2000) 52 out of 502 economists, $10.35 \%$, published at least one paper in the journals of the wide list.

Looking at the top of the Table 6, there are 15 researchers with five or more international publications, and two with more than 10 publications. Six of these top 15 productive scholars received their Ph.D. degrees in England, three in Cambridge, two in the University of Kent at Canterbury, one in Oxford. As seen above in Table 5, the majority of the scholars with top journal publications have an American Ph.D. This leads one to hypothesize that quantity and quality is attached to the place where the scholar studied, since it appears that the UK generates productive scholars, while the US generates scholars that emphasize publications in top journals. One, however, should be cautious about this inference because it is necessary to consider the whole universe of scholars in Brazil.

The top most productive researchers are distributed in eight departments: Five at FGV-RJ, three at UnB, two at PUC-RJ, and one each at UCB, UFRJ, UNICAMP, UFRGS, and USP. In 
Faria (2000) Table 6, there are 10 researchers with 5 or more international publications, and they are distributed in five departments: FGV-RJ, UnB, UFRJ, USP, and PUC-RJ. Therefore there is an increase in the number of highly productive researchers and they are distributed in a greater number of departments.

The leading Brazilian researchers Paulo Klinger Monteiro, Marilda Sotomayor and Aloísio Araújo happen to be among the most productive researchers as well. This is not a coincidence either. Influential economists tend to be highly productive and their influence is exercised by the sheer number of their papers as well as their publication in journals of high impact (see Faria, 2003).

When one contrasts the top economists with 5 or more international publications, displayed in Table 6, with Table 6 in Faria (2000), one sees that some names are a fixture, such as the above mentioned Paulo Klinger Monteiro, Marilda Sotomayor and Aloísio Araújo, plus Mauro Boianovsky, Joanílio Teixeira, both from UnB. Other productive economists in Faria (2000) left the country, Francisco Carneiro went to the World Bank and Flávio Menezes went to the University of Queensland, Australia. This also holds true in Table 6, since Jorge Arbache also went to the World Bank. However one cannot conclude that brain drain is taking place in Brazil, since some productive economists that were working abroad, such as Rodrigo Soares, Emanuel Ornelas and Walter Novaes, appear to have returned to Brazil.

There are 52 researchers with 2 or more international publications over the period 1999-2006. In Faria (2000) Table 6, there are 24 researchers with 2 or more international publications over the period 1983-1999. This shows that the production of research of international caliber has substantially improved in Brazil, with an increase in the number of papers, researchers and departments managing to publish in international journals of the wide list.

The journals where most of the articles published by Brazilian researchers appear are: Applied Economics, Applied Economics Letters, Economics Bulletin, Economics Letters, Economic Theory, History of Political Economy, Journal of Development Economics, Journal of Mathematical Economics, Journal of Post-Keynesian Economics, and World Development. As in Faria (2000) the areas in which Brazilian research is most internationally successful are: development economics, mathematical economics and post-keynesian economics. However, one additional area should be added to this list: applied economics. The "area" applied economics may involve papers in macroeconomics, microeconomics, international economics, labor and other specializations, however most of the papers classified as applied economics do not make a strong theoretical contribution, their role is to test well-known hypothesis using the state of the art econometric techniques, without attempting to develop these techniques. 


\section{Table 6}

\begin{tabular}{|c|c|c|c|c|}
\hline Name & Dept. & Ph.D. & Country & Publicat. \\
\hline Paulo Klinger Monteiro & FGV-RJ & IMPA & Brazil & 16 \\
\hline Mauro Boianovsky & UNB & Cambridge & UK & 12 \\
\hline Marilda Antonia de Oliveira Sotomayor & USP & PUC/RJ & Brazil & 9 \\
\hline Aloisio Pessoa de Araújo & FGV-RJ & Berkeley & USA & 8 \\
\hline Jorge Saba Arbache Filho & UNB & University of Kent at Canterbury & UK & 7 \\
\hline David Dequech & UNICAMP & Cambridge & UK & 7 \\
\hline João Victor Issler & FGV-RJ & University of California, San Diego & USA & 6 \\
\hline Ilan Goldfajn & PUC_RJ & M.I.T. & USA & 6 \\
\hline Ricardo Cavalcanti & FGV-RJ & University of Minnesota & USA & 5 \\
\hline Rubens Penha Cysne & FGV-RJ & EPGE/FGV & Brazil & 5 \\
\hline Rodrigo Reis Soares & PUC_RJ & University of Chicago & USA & 5 \\
\hline Ricardo S. A. Araújo & UCB & UNB & Brazil & 5 \\
\hline Flávio Vasconcellos Comim & UFRGS & Cambridge & UK & 5 \\
\hline Marcelo Resende & UFRJ & Oxford & UK & 5 \\
\hline Joanílio R. Teixeira & UNB & University of Kent at Canterbury & UK & 5 \\
\hline Marco Bonomo & FGV-RJ & Princeton University & USA & 4 \\
\hline Pedro Cavalcanti Ferreira & FGV-RJ & University of Pennsylvania & USA & 4 \\
\hline Walter Novaes & PUC_RJ & M.I.T. & USA & 4 \\
\hline Joaquim Pinto de Andrade & UNB & Harvard University & USA & 4 \\
\hline Fábio Kanczuk & USP & UCLA & USA & 4 \\
\hline Humberto Moreira & FGV-RJ & IMPA & Brazil & 3 \\
\hline Samuel Pessôa & FGV-RJ & USP & Brazil & 3 \\
\hline Emanuel Ornelas & IBMEC RJ & University of Wisconsin & EUA & 3 \\
\hline Maurício Bugarin & IBMEC-SP & University of Illinois & USA & 3 \\
\hline Adalmir Antonio Maquetti & PUC-RS & New School & USA & 3 \\
\hline Adolfo Sachsida & UCB & UNB & Brazil & 3 \\
\hline Jaime Orillo & UCB & IMPA & Brazil & 3 \\
\hline Wilfredo Leiva Maldonado & UCB & IMPA & Brazil & 3 \\
\hline Luiz Carlos Bresser Pereira & FGV_SP & USP & Brazil & 2 \\
\hline Fernando de Holanda Barbosa & FGV-RJ & University of Chicago & USA & 2 \\
\hline Luis H. B. Braido & FGV-RJ & University of Chicago & USA & 2 \\
\hline Renato Galvão Flôres Junior & FGV-RJ & UFRJ & Brazil & 2 \\
\hline Alexandre Barros da Cunha & IBMEC RJ & University of Minnesota & USA & 2 \\
\hline José Santiago Fajardo Barbachan & IBMEC RJ & IMPA & Brazil & 2 \\
\hline Marcelo de Albuquerque e Mello & IBMEC RJ & University Of Illinois & USA & 2 \\
\hline Eduardo de Carvalho Andrade & IBMEC-SP & University of Chicago & USA & 2 \\
\hline Naércio Aquino Menezes Filho & IBMEC-SP & University of London & UK & 2 \\
\hline Pedro Valls Pereira & IBMEC-SP & London School of Economics & UK & 2 \\
\hline Márcio Gomes Pinto Garcia & PUC_RJ & Stanford University & USA & 2 \\
\hline José Ângelo Costa do Amor Divino & UCB & Boston University, BU & USA & 2 \\
\hline Luiz Fernando Rodrigues de Paula & UERJ & UNICAMP & Brazil & 2 \\
\hline Marco Crocco & UFMG & University of London & UK & 2 \\
\hline Fernando Ferrari Filho & UFRGS & USP & Brazil & 2 \\
\hline Eduardo Pontual Ribeiro & UFRJ & University Of Illinois & USA & 2 \\
\hline Fernando José Cardim de Carvalho & UFRJ & Rutgers University & USA & 2 \\
\hline Bernardo P.M. Mueller & UNB & University of Illinois & USA & 2 \\
\hline Carlos Alberto Cinquetti & UNESP & New School for Social Research. & EUA & 2 \\
\hline Carlos Roberto Azzoni & USP & IPE/USP & Brazil & 2 \\
\hline Denisard Cnéio de Oliveira Alves & USP & Universidade de Yale & USA & 2 \\
\hline Eduardo Amaral Haddad & USP & University of Illinois & USA & 2 \\
\hline Gilberto Tadeu Lima & USP & University of Notre Dame & USA & 2 \\
\hline Joaquim José Martins Guilhoto & USP & University of Illinois & USA & 2 \\
\hline Paulo Picchetti & USP & University of Illinois & USA & 2 \\
\hline Adriana Schor & FGV_SP & USP & Brazil & 1 \\
\hline Carmen Augusta Varela & FGV_SP & FGV-EAESP & Brazil & 1 \\
\hline Eduardo Matarazzo Suplicy & FGV_SP & Michigan State University & USA & 1 \\
\hline Carlos E. da Costa & FGV-RJ & University of Chicago & USA & 1 \\
\hline Luiz Renato Lima & FGV-RJ & University of Illinois & USA & 1 \\
\hline
\end{tabular}




\begin{tabular}{|c|c|c|c|c|}
\hline Name & Dept. & Ph.D. & Country & Publicat. \\
\hline Marcos de Barros Lisboa & FGV-RJ & University of Pennsylvania & USA & 1 \\
\hline Maria Cristina Terra & FGV-RJ & Princeton University & USA & 1 \\
\hline Antonio C. Fiorêncio Soares da Cunha & IBMEC RJ & Ec. Hautes Etudes en Sc.Soc.,EHESS & France & 1 \\
\hline Fabio Ribas Chaddad & IBMEC-SP & University of Missouri Columbia & USA & 1 \\
\hline José Luiz Rossi Júnior & IBMEC-SP & Yale University & USA & 1 \\
\hline Gustavo Maurício Gonzaga & PUC_RJ & Berkeley & USA & 1 \\
\hline Juan Pablo Torres-Martínez & PUC_RJ & IMPA & Brazil & 1 \\
\hline Juliano Junqueira Assunção & PUC_RJ & PUC-Rio & Brazil & 1 \\
\hline Marcelo Cunha Medeiros & PUC_RJ & PUC-Rio & Brazil & 1 \\
\hline Marcelo de Paiva Abreu & PUC-RJ & Cambridge & UK & 1 \\
\hline Paulo Roberto Amorim Loureiro & UCB & UNB & Brazil & 1 \\
\hline Tito Belchior da Silva Moreira & UCB & UNB & Brazil & 1 \\
\hline Joilson Dias & UEM & University Of South Carolina & USA & 1 \\
\hline Antônio Salazar Pessoa Brandão & UERJ & Purdue University & USA & 1 \\
\hline Gervásio Castro de Rezende & UFF & University of Wisconsin & USA & 1 \\
\hline Fernando Salgueiro Perobellil & UFJF & USP & Brazil & 1 \\
\hline Edson Domingues & UFMG & USP & Brazil & 1 \\
\hline Frederico Gonzaga Jayme Junior & UFMG & New School for Social Research & USA & 1 \\
\hline Mauro Borges Lemos & UFMG & University of London & UK & 1 \\
\hline José Luis da Costa Oreiro & UFPR & UFRJ & Brazil & 1 \\
\hline Flávio Augusto Ziegelmann & UFRGS & University Of Kent & UK & 1 \\
\hline Franklin Leon Peres Serrano & UFRJ & Cambridge & UK & 1 \\
\hline João de Deus Sicsú Siqueira & UFRJ & UFRJ & Brazil & 1 \\
\hline Valéria Lúcia Pero & UFRJ & UFRJ & Brazil & 1 \\
\hline André L.Rossi de Oliveira & UNB & University of Illinois & USA & 1 \\
\hline Maria Conceição Sampaio de Sousa & UNB & Universite Libre de Bruxelles & Belgium & 1 \\
\hline Maria Luiza Falcão Silva & UNB & Heriot Watt University & UK & 1 \\
\hline Antonio Carlos Coelho Campino & USP & FEA/USP & Brazil & 1 \\
\hline Elizabeth M. Mercier Querido Farina & USP & USP & Brazil & 1 \\
\hline Fabiana Fontes Rocha & USP & University of Illinois & USA & 1 \\
\hline Fernando Antonio Slaibe Postali & USP & USP & Brazil & 1 \\
\hline Joe Akira Yoshino & USP & University of Chicago & USA & 1 \\
\hline Márcio Issao Nakane & USP & University of Oxford & UK & 1 \\
\hline Vera Lúcia Fava & USP & IPE/FEA/USP & Brazil & 1 \\
\hline Eliezer Martins Diniz & USP-RP & USP & Brazil & 1 \\
\hline Maria Dolores Montoya Diaz & USP-RP & USP & Brazil & 1 \\
\hline Reynaldo Fernandes & USP-RP & USP & Brazil & 1 \\
\hline Walter Belluzzo Junior & USP-RP & University Of Illinois & USA & 1 \\
\hline
\end{tabular}

\section{DISCUSSION}

As discussed in Faria (2000) every ranking is controversial. In our case, the choice of journals in the wide list of journals is debatable ${ }^{9}$ as well as our choice of ranking scholars purely on absolute number of publications without taking into account the relative importance of journals and coauthorship.

In a recent evaluation of Brazilian economics departments elaborated by Issler et al. (2007) the comparison of evaluations made with two different journal rankings lists, Kalaitzidakis et al. (2003) and Capes, shows that Brazilians researchers that according with Capes criteria are publishing in high quality journals, when measured by the impact factor of Kalaitzidakis et al. (2003) are publishing in low impact journals.

9 See Faria (2002) for a survey on journal rankings. 
Capes list is an ad hoc ranking, made by consultation with a limited group of Brazilian economists, while Kalaitzidakis et al. (2003) is based on the impact factor of journals. A priori Kalaitzidakis et al. (2003) would provide a better way to weigh publications of scholars. However, one has to bear in mind that their criteria has its own problems. For instance, take into consideration this appalling characteristic of Kalaitzidakis et al. (2003) impact factor: The Journal of Mathematical Economics and Journal of Econometrics are two leading journals in the fields of mathematical economics and econometrics, respectively. No one a priori would dare to give them extremely unequal weights. However according to Kalaitzidakis et al. (2003) impact factor, one paper published in the Journal of Econometrics, that has an impact factor of 54.91, is worth about 7 papers published in the Journal of Mathematical Economics, with an impact factor of 7.64.

As said before, the Brazilian performance in international publications is poor if compared with other countries. ${ }^{10}$ Faria $(2000,2001,2004,2005)$ and Faria et al. (2007) discussed in detail some of the causes of the poor research performance of the Brazilian academic economists such as rent-seeking, lack of incentives in public institutions, lack of international networks, the peculiarities of the Brazilian research in economics, etc. Here we rather discuss the relative observed improvement over the two periods covered by Faria (2000) study and the present study.

The noticeable increase in the numbers of papers, scholars and departments with members publishing in international journals over the period of 1999-2006 as compared to 1983-1999 can be associated with the following factors: i) incentives for publication; ii) generational effect; and iii) competition.

The incentives for publication in international journals take different forms in Brazil. In private institutions, with greater flexibility than public universities, the incentives are reflected in higher salaries, greater job mobility and direct pecuniary gains for publishing internationally. The incentives provided by public research agencies such as Capes and Cnpq take the form of higher grants for research, travel and study abroad for research recycling and network formation. ${ }^{11}$ Over the past decade the number of private institutions has grown substantially and the government research agencies have reviewed some of their incentives increasing the relative importance of international publications.

The generational effect can be clearly seen by noticing that most of the new names that appear in Table 6 are names of researchers that finished their Ph.D. degrees over the past few years. Anecdotal evidence suggests that the younger generation is better prepared technically than the older generation. The advent of personal computers, econometric softwares of easy operation and new and free data sets made it cheaper to carry empirical research, help explaining the high growth rate of the "applied economics" field in Brazil. The new generation also has greater exposure to international research than the previous generation, mainly because the internet has cut the research costs and increased the communication among researchers worldwide. Over the past decade a number of new Ph.D. programs in economics were opened in Brazil, making it cheaper for many students to get a Ph.D. degree. The new graduate programs increased the demand for and supply of newly minted Ph.Ds. All these factors working together promoted quality research reflected in international publications.

10 See, among others, Neri and Rodgers (2006) for Australia, Barrett and Lucey (2003) for Ireland, Çokgezen (2006) for Turkey, Gregor and Schneider (2005) for Czech Republic, Lucas (1995) for Canada, Kalaitidakis et al. (1999) and Tombazos (2005) for Europe, Jin and Yau (1999) for east Asia.

11 Faria (2004) has a length discussion about the incentives provided by Brazilian public research agencies. 
The better illustration of the workings of these factors is given by the scholars of UCB. There are seven UCB professors in the list of the most productive researchers in Brazil. Six researchers received their Ph.D. degrees in Brazil four at UnB, and two at IMPA; five of them graduated after 2000. They are from the same generation, having studied together under the same professors and developed similar research agendas and publishing strategies. One can also note that they have a high rate of co-authorship among themselves and with their former professors at IMPA and UnB. Actually, the good performance of some UnB scholars is clearly linked to the achievements of these former students. ${ }^{12}$

At this point one has to stress the role of individuals as research leaders shaping generations of researchers. The best example is Aloísio Araújo, whose leadership at IMPA helped educate generations of highly gifted and productive researchers. The Peruvian connection illustrates this point. There are four researchers from Peru in our sample: José Barbachan, Wilfredo Maldonado, Jaime Orrillo and Juan Pablo Torres-Martinez. All of them have studied and published with Aloísio Araújo. Besides that if one adds the names of Paulo Klinger Monteiro and Humberto Moreira, that also studied and published with Aloísio Araújo, one must conclude that the entire field of mathematical economics in Brazil, and its international projection, would not exist without him.

Competition has helped research in economics in Brazil because new centers were created, enlarging employment and salary opportunities for scholars. Some of these new schools are private, with greater interest in acquiring a good reputation for themselves, as the case of IBMEC of Rio de Janeiro and São Paulo. Besides the competition of schools for recognition, grants and good students, there is competition at the individual level. Before the growing consensus that academic merit is objectively measured through publications and citations, the best way for a Brazilian economist to get reputation was by entering in a reputed economics department, and by writing op-ed articles in newspapers, appearing in the news pretending to be specialists about anything journalists asked about and by engaging in politics and being referred by politicians as good economists. Fortunately this appears to be changing nowadays, at least in some academic circles, where an economist gains reputation through his/her published work, the impact of his/her work on other researchers' work and by seminar and conference presentations, where they are under close scrutiny by their peers. This generates a healthy competition because most of the scholars play this race, among other objectives, to gain reputation and respect. Publications in peer review international journals are an efficient way to achieve this type of success.

\section{CONCLUDING REMARKS}

This paper extends Faria (2000) analysis to the period of 1999-2006. The study analyzed the production of 750 Brazilian academic economists from 31 departments of economics with graduate programs. The publications were assessed through the online Econ-Lit database.

At individual level, only 12 out of 750 economists managed to publish at least one paper in the top journals of economics, and 96 economists published at least one paper in a wide list of international journals. The areas in which Brazilian research is internationally successful are: Applied economics, development economics, mathematical economics and post-keynesian economics. As in

12 On co-authorship see Sutter and Kocher (2004). 
Faria (2000) there is a remarkable difference in quality among the departments. The performance of departments depends on isolated individual's efforts and achievements.

This paper documents a relative improvement in the international research in economics in Brazil. When compared with the period of 1983-1999 covered by Faria (2000), it becomes clear that the number of papers, the number of researchers and departments with members publishing in international journals has increased over the period 1999-2006.

\section{REFERENCES}

AZZONI, C. R. "Clássicos" da literatura econômica brasileira: trabalhos e autores mais citados nas nossas revistas acadêmicas. Economia Aplicada, v. 2, p. 771-780, 1998.

. Desempenho das revistas e dos departamentos de economia brasileiros segundo publicações e citações recebidas no Brasil. Economia Aplicada, v. 4, p. 787-822, 2000.

BARRETT, A.; LUCEY, B. An analysis of the journal article output of Irish-based economists, 1970-2001, Economic and Social Review, v. 34, p. 109-143, 2003.

BESANCENOT, D.; VRANCEANU, R. Can incentives for research harm research? A business school's tale. Journal of Socio-Economics, 2007. forthcoming.

COUPÉ, T. Revealed performances: Worldwide rankings of economists and economics departments, 1990-2000. Journal of the European Economic Association, v. 1, p. 1309-1345, 2003.

ÇOKGEZEN, M. Publication performance of economists and economics departments in Turkey (19992003). Bulletin of Economic Research, v. 58, p. 253-265, 2006.

DUSANSKY, R.; VERNON, C. Rankings of US economics departments. Journal of Economic Perspectives, v. 12, n. 1, p. 157-170, 1998.

FARIA, J. R. The research output of academic economists in Brazil. Economia Aplicada v. 4, p. 95-113, 2000. 2001.

. Rent seeking in academia: The consultancy disease. American Economist, v. 45, p. 69-74,

. An analysis of rankings of economic journals. Brazilian Journal of Business Economics, v. 2, p. $95-117,2002$.

. What type of economist are you: r-strategist or K-strategist? Journal of Economic Studies, v. 30, p. 144-154, 2003.

. Some reflections on incentives for publication: The case of the CAPES' list of economic journals, Economia Aplicada, v. 8, p. 791-816, 2004.

. Is there a trade-off between domestic and international publications? Journal of Socio-Economics, v. 34, p. 269-280, 2005.

.; Araújo Jr., A.; Shikida, C. D. The citation pattern of Brazilian economists. Estudos Econômicos, v. 37, p.151-166, 2007.

FOX, K. J.; MILBOURNE, R. What determines research output of academic economists? Economic Record, v. 75, p. 256-267, 1999.

FRANCO, G. Economia na PUC-Rio: notas de uma testemunha, 2007. Disponível em: < http://www.econ. puc-rio.br/gfranco/Economia\%20na\%20PUC_Versao_revista_EB.pdf $>$.

GARCIA-CASTRILLO, P.; MONTANES, A.; SANZ-GRACIA, F. A worldwide assessment of scientific production in economics (1992-1997). Applied Economics, v. 34, p. 1453-1475, 2002.

GONÇALVES, R; DAVID, M. D. A produção acadêmica nas principais revistas de economia: Balanço de uma década. Literatura Econômica, v. 4, p. 283-380, 1982. 
GREGOR, M.; SCHNEIDER, O. The world is watching: rankings of Czech and Slovak economics departments. Czech Journal of Economics and Finance, v. 55, p. 518-530, 2005.

ISSLER, J. V.; Pillar, T. Mensurando a produção científica internacional em economia de pesquisadores e departamentos brasileiros. Pesquisa e Planejamento Econômico, v. 32, p. 323-381, 2002.

.; Ferreira, R.C. Avaliando pesquisadores e departamentos de economia no Brasil a partir de citações internacionais. Pesquisa e Planejamento Econômico, v. 34, p. 491-538, 2004.

.; Ourives, L.; Santos, C.; Severo, T. Tabelas comparando departamentos atuais de Economia no Brasil: Avaliação para o período 2004-2006 e outras comparações, 2007. Disponível em: < http://epge. fgv.br/blogs/news/files/2007/05/tabelaspublicacaocitacaodepartamentos2001-2006_final.pdf >.

JIN, J.; YAU, L. Research productivity of the economics profession in East Asia. Economic Inquiry, v. 37, p. 706-710, 1999.

KALAITZIDAKIS, P.; MAMUNEAS, T. P.; STENGOS, T. European economics: an analysis based on publications in the core journals. European Economic Review, v. 43, p. 1150-1168, 1999.

Rankings of academic journals and institutions in Economics. Journal of the European Economic Association, v. 1, p. 1346-1366, 2003.

KIM, E.; MORSE, A.; ZINGALES, L. What has mattered to economics since 1970. Journal of Economic Perspectives, v. 20, p. 189-202, 2006.

LABAND, D.N.; PIETE, M. J. The relative impacts of economics journals: 1970-1990. Journal of Economic Literature, v. 32, p. 640-666, 1994

LUCAS, R. Contributions to economics journals by the Canadian economics profession, 1981-1990. Canadian. Journal of Economics, v. 28, p. 949-960, 1995.

NERI, F.V.; Rodgers, J. R. Ranking Australian Economics departments by research productivity. Economic Record, v. 82, p. S74-S84, 2006.

SAMUELSON, P. A. In: Breit, W.; Spencer, R. (Eds.). Lives of the Laureates. Cambridge: MIT Press, 1995.

SUTTER, M.; KOCHER, M. Patterns of co-authorship among economics departments in the USA. Applied Economics, v. 36, p. 327-333, 2004.

TOMBAZOS, C. G. A Revisionist perspective of European research in economics. European Economic Review, v. 49, p. 251-277, 2005. 


\section{APPENDIX}

\section{List of journals}

- American Economic Review

- American Journal of Agricultural Economics

- Annals of Regional Science

- Applied Economics

- Applied Financial Economics

- Australian Economic's Papers

- Brookings Papers on Economic Activity

- Bulletin of Economic Reseacrh

- Cambridge Journal of Economics

- Camegie-Rochester Conference Series on Public Policy

- Canadian Journal or Economics

- Computational Economics

- Constitutional Political Economy

- Contemporary Economic Policy

- Ecological Economics

- Econometric Reviews

- Econometric Theory

- Econometrica

- Econometrics Journal

- Economic Development and Cultural Change

- Economic History Review

- Economic Inquiry

- Economic Journal

- Economic Modelling

- Economic Record

- Economic Theory

- Economica

- Economics Letters

- Empirica

- Empirical Economics

- Energy Economcis

- Energy Journal

- European Economic Review

- European Journal of Political Economy

- European Journal of the History of Economic Thought 
- Explorations in Economic History

- Fiscal Studies

- Games and Economic Behavior

- Geneva Papers on Risk and Insurance Theory

- History of Political Economy

- IMF Staff Papers

- Industrial and Labor relations Review

- International Economic Review

- International Game Theory Review

- International Journal of Game Theory

- International Journal of Industrial Organization

- Japan and the World Economy

- Journal of American Statistical Association

- Journal of American Statistical Association

- Journal of Applied Econometrics

- Journal of Applied Economics

- Journal of Banking and Finance

- Journal of Business

- Journal of Business and Econ. Statistics

- Journal of Comparative Economics

- Journal of Development Economics

- Journal of Development Studies

- Journal of Econometrics

- Journal of Economic Behavior and Organization

- Journal of Economic Dynamics and Control

- Journal of Economic Education

- Journal of Economic Growth

- Journal of Economic History

- Journal of Economic Literature

- Journal of Economic Perspectives

- Journal of Economic Review

- Journal of Economic Studies

- Journal of Economic Theory

- Journal of Economics

- Journal of Environmental Economics and Management

- Journal of Finance

- Journal of Financial and Quantitative Analysis

- Journal of Financial Economics 
- Journal of Health Economics

- Journal of Human Resources

- Journal of Industrial Economics

- Journal of Institutional and Theoretical Economics

- Journal of International Economics

- Journal of International Money and Finance

- Journal of Labor Economics

- Journal of Labor Research

- Journal of Law and Economics

- Journal of Macroeconomics

- Journal of Mathematical Economics

- Journal of Monetary Economics

- Journal of Money Credit and Banking

- Journal of Policy Modeling

- Journal of Political Economy

- Journal of Post Keynesian Economics

- Journal of Productivity Analysis

- Journal of Public Economic Theory

- Journal of Public Economics

- Journal of Risk and Uncertainty

- Journal of Socio-Economics

- Journal of the Royal Statistical Society (All Series)

- Journal of Urban Economics

- Kyklos

- Labor

- Labour Economics

- Land Economics

- Macroeconomics Dynamics

- Manchester School

- Mathematical Finance

- Mathematical Social Sciences

- Metroeconomica

- National Tax Journal

- NBER Macroeconomics Annual

- Oxford Bulletin of Economics and Statistics

- Oxford Economic Papers

- Papers in Regional Science

- Public Choice 
- Public Finance Review

- Quarterly Journal of Economics

- Quarterly Review of Economics and Finance

- Rand/Bell Journal of Economics

- Regional Science and Urban Economics

- Research in Economics

- Review of Development Economics

- Review of Economic Design

- Review of Economic Dynamics

- Review of Economic Studies

- Review of Economics and Statistics

- Review of Income and Wealth

- Review of International Economics

- Review of Political Economy

- Scandinavian Journal of Economics

- Scottish Journal of Political Economy

- Social Choice and Welfare

- Southern Economic Journal

- Structural Change and Economic Dynamics

- Studies in Nonlinear Dynamics and Econometrics

- Theory and Decision

- Weltwirtschaftliches Archiv

- World Development 